\title{
A Methodological Approach for Testing the Viability of Seeds Stored in Short-Term Seed Banks
}

\author{
José A. FORTE GIL ${ }^{1}$, Lourdes YABOR ${ }^{2,5}$ Antonio BELLIDO NADAL ${ }^{3}$, \\ Francisco COLLADO ${ }^{3}$, Pablo FERRER-GALLEGO ${ }^{4,6}$, \\ Oscar VICENTE ${ }^{2}$, Monica BOSCAIU ${ }^{1 *}$ \\ ${ }^{1}$ Universitat Politécnica de València, Mediterranean Agroforest Institute (IAM), Camino de Vera s/n, 46022, Valencia, \\ Spain; joforgi@etsiamn.upv.es; mobosnea@eaf.upv.es (*correspondingauthor) \\ ${ }^{2}$ Universitat Politécnica de València, Institute of Plant Molecular and Cellular Biology (IBMCP, UPV-CSIC), Camino de Vera s/n, 46022, \\ Valencia,Spain; lyabor@bioplantas.cu; ovicente@ibmcp-upv.es \\ ${ }^{3}$ Servici Devesa-Albufera, Vivers Municipals de El Saler, CV-500, $\mathrm{km} 8.5,46012$, Valencia, \\ Spain; tono.bellido@gmail.com; fjcollado@valencia.es \\ ${ }^{4}$ Servicio de Vida Silvestre, Centro para la Investigación y Experimentación Forestal de la Generalitat Valenciana (CIEF), Avda. Comarques del \\ Pais Valencià, 114, ES-46930 Quart de Poblet, València, Spain; flora.cief@gva.es \\ ${ }^{5}$ Bioplantas Center, University of Ciego de Avila, Cuba (permanent address) \\ ${ }^{6}$ VAERSA, Avda. de les Corts Valencianes, 20, ES-46015 València, Spain
}

\begin{abstract}
Efficient management of 'active' seed banks - specifically aimed at the short-term storage at room temperature of seeds to be used locally in conservation/regeneration programmes of endemic or endangered plant species - requires establishing the optimal storage time to maintain high seed viability, for each stored species. In this work, germination of seeds of the halophytes Thalictrum maritimum, Centaurea dracunculifolia and Linum maritimum has been investigated. The seeds had been stored for different periods of time in the seed bank of 'La Albufera' Natural Park (Valencia, SE Spain) after collection in salt marshes of the Park, where small populations of the three species are present. Seeds of T. maritimum and C. dracunculifolia have a relatively short period of viability at room temperature, and should not be stored for more than three years. On the other hand, L. maritimum seeds maintain a high germination percentage and can be kept at room temperature for up to 10 years. T. maritimum seeds, in contrast to those of the other two species, did not germinate in in vitro tests nor when sown directly on a standard substrate, unless a pre-treatment of the seeds was applied, mechanical scarification being the most effective. These results will help to improve the management of the seed bank, to generate more efficiently new plants for reintroduction and reinforcement of populations of these species in their natural ecosystems within the Natural Park.
\end{abstract}

Keywords: Centaurea dracunculifolia, Linum maritimum, germination percentage, Thalictrum maritimum, germination rate, seed banks, seed viability

\section{Introduction}

Traditionally, the ex situ conservation of plant species has been based on the maintenance of unique species in the botanical gardens. Over time, it was understood that simple collections consisting of only a few individuals of the taxa of interest did not represent the best form of conservation and that an excellent way to increase the genetic variability of the collections was through germplasm banks (Heywood, 2003; Guerrant et al., 2004; Hernández-Bermejo, 2007). Any living plant matter from which new plants can be grown such as viable cells, plant explants, zygotic and somatic embryos, calli or other tissue culture samples - can be stored for conservation in germplasm banks. Yet, most often, seeds are the material of choice, as seed storage is certainly the simplest and most efficient method for ex situ preservation of plant genetic resources; therefore, the largest proportion of germplasm banks are, in fact, seed banks. Optimal storage conditions include keeping the seeds at low humidity in 
564

hermetically closed containers and, generally, at low temperature $\left(-18{ }^{\circ} \mathrm{C}\right.$ or below, or even cryopreserved at ultralow temperatures in liquid $\mathrm{N}_{2}$ ); such conditions guarantee to maintain high levels of seed viability over extended time periods (Pritchard \& Dickie, 2003; Benson, 2008).

Today, hundreds of botanical gardens have their own seed banks, retaining more than one-third of the world's wild species (Iriondo, 2001). In the past, germplasm banks were mainly oriented to the conservation of food crops, but after the Earth Summit in Rio de Janeiro in 1992, there was a boost on the conservation of seeds of rare, endemic and threatened wild species (see Godefroid et al., 2011). Germplasm banks do not exist only in the botanical gardens, as many local administrations have also implemented this conservation methodology. The main objective of this type of germplasm banks is to preserve the genetic diversity of plant species (see Hoban and Schlarbaum, 2014), as well as to protect against natural or human-produced disasters, which may take place in the areas where conservation is carried out in situ (Cuevas, 1988; ENSCONET, 2009; BGCI, 2012; FAO, 2013).

Currently, it is recommended to maintain centres dedicated to the development of ex situ conservation programmes for endangered species, to achieve the targets of the 'Global Strategy for Plant Conservation' (GSPC), proposed by the Convention on Biological Diversity (CBD). The strategy was originally adopted in 2002 and updated in 2010 (Sharrock and Jones 2011; Sharrock et al., 2014), focusing on the conservation of plants and fungi to halt the loss of biodiversity (CBD, 2002;2012). Revised and updated, its last version (2011-2020) provides a legal framework and targets for accessing, conserving and using biodiversity in a fair and equitable manner.

Germplasm banks are a valuable tool for carrying out $e x$ situ preservation, both as preventive action, as conservation of plant diversity or even as an urgent response to the extinction of species or populations (Bacchetta et al., 2008). Within their large diversity, a special category is represented by those seed banks directly associated with the management of protected areas, which usually store seeds at a short time scale, to be directly used in natural habitats for population's reinforcement or reintroduction of rare or endemic species.

The conservation of plant species in the Valencian Community (Spain) has been undertaken using an integrated approach developed over several decades. Since the 1980s, a great effort has been made by the Community administration and other organisations, which led to the publication of the Valencian Catalogue of Threatened Plant Species (VCTPS) (Aguilella et al. 2010). The conservation strategy includes in situ and ex situ components, applied in a series of steps (Ferrer-Gallego et al. 2013). The in situ activities (first step) focus on the diagnosis of the actual status of the species in the wild (threat detection, assessment of the real situation in natural populations, georeferenced network, search of new individuals, etc.); ex situ conservation, the second step, is implemented by creating long-term collections at the Botanical Garden of the University of Valencia, and short-term or active collections at the Centre for Forestry Research and Experimentation
(CIEF), at the Freshwater Species Research Center and, in addition, a specific seed bank in the Devesa-Albufera Service, responsible for management of 'La Albufera' Natural Park (Valencia province) (Ferrer-Gallego et al., 2014). The latter stores seeds of species of interest collected in the Natural Park, used for reinforcement of natural populations and recovery of degraded habitats in the area.

The seed bank of 'La Albufera' Natural Park started as a simple nursery for the production of the plant material necessary for the restoration of the vegetal cover; over time, however, its facilities have been expanded, and the number of samples and the number of stored species increased, to address also the conservation of local genetic diversity. The seed bank currently includes more than 170 different species growing in this area, practically all characteristic species of the different ecosystems of the Natural Park. Management of this seed bank is an example of complementation between in situ and ex situ conservation programmes, producing outside the habitat new specimens, which are later used for the conservation work in the natural environment. Only the synergistic application of in situ and ex-situ conservation strategies can ensure good management of endangered species (Laguna, 1998; Volis and Blecher, 2010; Heywood, 2015; Volis, 2016).

As seeds are primarily used to produce plants for the reinforcement of natural populations, rather than for conservation of genetic material, preservation is not intended for long periods of time and the seeds are stored at room temperature. For this reason, seed viability is reduced over time much faster than for seeds stored at low temperatures. Since limited storage space is a major problem in such seed banks, an important tool for their efficient management is the systematic study of seed viability loss in different species.

In view of this problem, it was decided to analyse the viability of seeds collected in different years, and therefore stored for variable times, belonging to three salt marsh species: Thalictrum maritimum L., Linum maritimum L. and Centaurea dracunculifolia Dufour. The three species are present in the area of the park, but their populations are quite small, which makes likely the necessity of reinforcement of their populations in the future. For this reason, it is important to maintain a close monitoring of these species and ensure the availability of stocks of seeds with good germination capacity.

The specific aims of the work were (1) to determine the relative maintenance of germination capacity of the seeds over the years, to establish the optimal storage period for the three species, and (2) to establish appropriate germination protocols to ensure higher percentages of germination.

\section{Materials and Methods}

\section{Selectedspecies}

The three species appear in the area of 'La Albufera' Natural Park, on low and moderate saline soils in salt marshes or coastal lagoons (Mansanet, 1979; Lidón et al., 2009; Mateo and Crespo, 2014). Thalictrum maritimum L. (Ranunculaceae) is an endemic species of the Valencian coast (provinces of Valencia and Castellón) and Tarragona province (Catalonia) (Bolòs and Vigo, 1984; Montserrat, 
1986; Bolòs et al., 2005; Curcó, 2007; Ferrer-Gallego et al., 2015), classified as VU (vulnerable) in the Spanish Red List of Vascular Plants (Bañares et al., 2006), and in the Valencian Catalogue of Threatened Flora Species (Aguilella et al., 2010; CITMA, 2013). Centaurea dracunculifolia Dufour (Asteraceae) is an Iberian endemic, distributed in SE Spain, and represented by disperse populations in the coast of Valencia. It is classified under the IUCN category LR / NT (Less risk / Near threatened). Linum maritimum L. (Linaceae) is distributed throughout the Mediterranean basin, without UICN category but with interest in the region of the Natural Park, where its populations are scarce.

\section{Seed material}

Fully mature seeds or fruits were collected in different years, from natural populations present in 'La Albufera' Natural Park, selecting as many different individuals as possible in each sampling (Table 1). Seeds were cleaned and dried using silica gel, until the moisture content decreased to $\sim 8 \%$, and then kept in airtight plastic bags in an airconditioned room where the temperature did not exceed $20-22^{\circ} \mathrm{C}$.

\section{Germination tests}

The tests were performed on standard Petri dishes $(9 \mathrm{~cm}$ diameter) with a sterile cotton layer covered by two layers of filter paper, which had been wetted with $25 \mathrm{ml}$ of milliQ water. For each species and collection year, three Petri dishes, with 20 seeds per plate, were used in the germination tests. Prior to germination, seeds were disinfected with commercial bleach for $10 \mathrm{~min}$, and then thoroughly washed with milliQ water.

Seeds were germinated in a germination chamber (Equitec, EGCHS HR), with a photoperiod of 16 hours of light at $30{ }^{\circ} \mathrm{C}$, and 8 hours of darkness at $20^{\circ} \mathrm{C}$. The number of germinated seeds was recorded every two days, during one month; a seed was considered as germinated when the radicle emerged and acquired a size of 2 to $3 \mathrm{~mm}$. The percentages of germination were calculated as means of the three replicates for each species, collection year and treatment. The germination velocity was estimated by calculating the 'Mean Germination Time' (MGT), as described by Ellis and Roberts (1981):

$$
\mathrm{MGT}=\Sigma \mathrm{Dn} / \Sigma \mathrm{n},
$$

where $\mathbf{D}$ is 'days from the beginning of the germination test', and $\mathbf{n}$ is the number of seeds newly germinated on day D.

\section{Pre-treatments of seeds of Thalictrum maritimum}

The results of preliminary germination tests indicated a low germination capacity of $T$. maritimum seeds. Therefore, several methods for stimulation of germination were applied in this species, as described below.

Chemical scarification. The seeds were immersed in $96 \%(\mathrm{v} / \mathrm{v}) \mathrm{H}_{2} \mathrm{SO}_{4}$ for twenty seconds, then rinsed with distilled water, disinfected and placed in the Petri dishes.

Mechanical scarification. Fruits were open and the sample was rubbed with a fine-grain sandpaper; the extracted seeds were cleaned, disinfected with bleach and transferred to the Petri dishes.

Treatment with gibberellic acid (AG3). Before the germination test, clean and disinfected seeds were placed in a Petri dish and covered with a $200 \mathrm{ppm}$ AG3 solution and kept at room temperature for 24 hours.

\section{Direct sowing of seeds in substrate}

As an alternative to the germination tests in Petri dishes, disinfected seeds without any other pre-treatment were sown directly in small pots in a standard substrate $(50 \%$ peat, $25 \%$ perlite, and $25 \%$ vermiculite). Only seeds of the lots collected in 2016, of the three selected species, were used in these assays.

\section{Seed viability testing}

This test was carried out only with seeds of $T$. maritimum, the most problematic species. Seeds were scarified to separate the seed coat and were then soaked in water for 24 hours at room temperature. Seeds were collected and incubated in a $1 \%$ tetrazolium chloride solution at $30^{\circ} \mathrm{C}$ for additional 24 hours in the dark.

Seeds were classified into three groups, according to the results of the tetrazolium test (Craviotto and Arango, 2005). Those with completely stained embryo and cotyledons are considered as viable, while those non-stained or with only the embryo or only the cotyledons stained are defined as not viable. A third group includes seeds in which the embryo, as well as the nutritional tissue, has been stained, but some parts remained uncoloured; in this case, it is not clear whether the seeds are losing viability, are viable with defects or simply have been damaged during the test.

\section{Statistical treatment of the data}

To assess the significance of the differences observed in the germination tests between the lots of seeds collected in different years, for each of the selected species, as well as between pre-treatments in the case of T. maritimum, a oneway ANOVA was applied after a previous arcsin transformation of the data. Statistical analysis was carried out with the Statgraphics Centurion XV programme.

\section{Results}

\section{Thalictrum maritimum}

Due to the low germination percentages of $T$. maritimum seeds observed in preliminary assays, different pre-treatments were carried out to try and improve this process. Seeds of the two most recent years (2015 and 2016) were subjected to chemical or mechanical scarification, or to treatment with gibberellic acid; control seeds not pretreated in any way did not germinate at all (not shown). The highest percentages of germination - over $50 \%$ of the seeds at the end of the test - were obtained after mechanical scarification (Fig. 1). When comparing the two years, slightly better results were obtained with seeds from 2016 (Fig. 1A). For the seeds sampled in 2015, final percentages of germination after chemical scarification or treatment with gibberellic acid were considerably lower than after mechanical scarification (Fig. 1B), whereas the differences were not so big for 2016 seeds (Fig. 1A). 

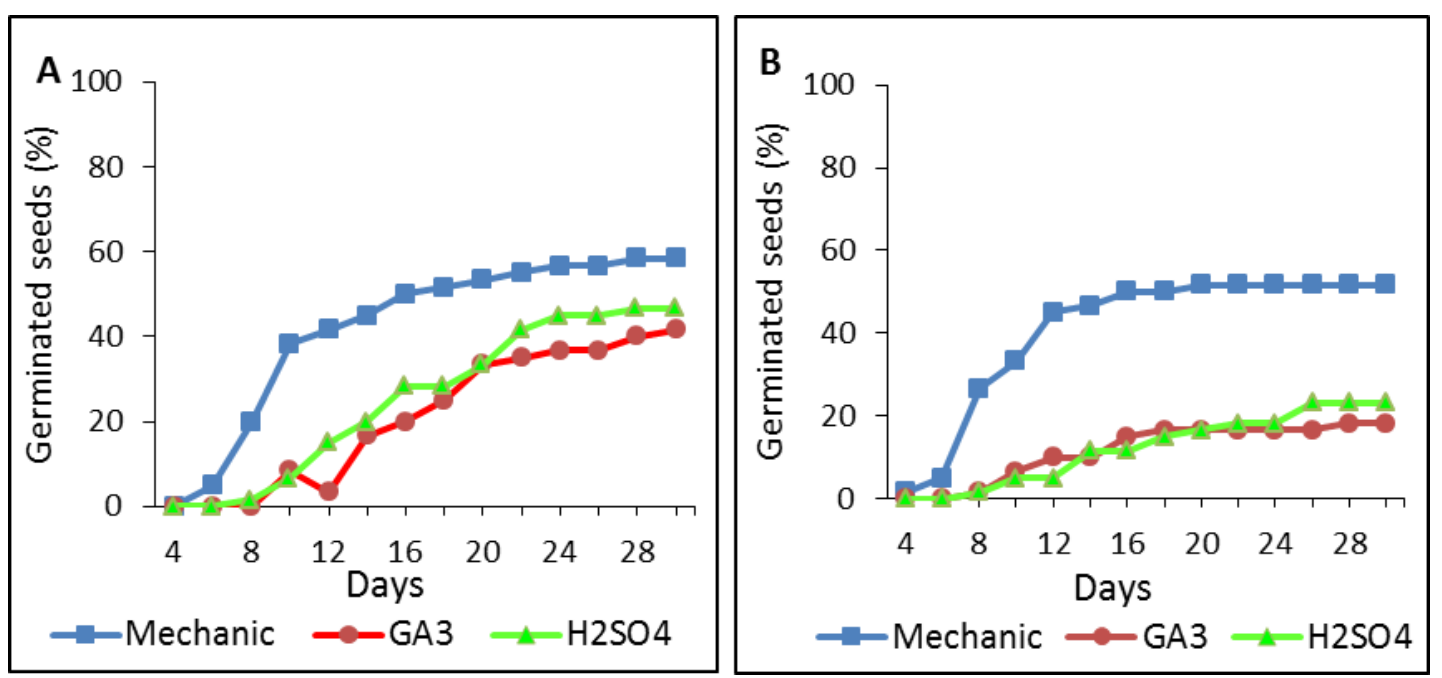

Fig. 1. Effect of the indicated pre-treatments on seed germination kinetics and germination percentages for Thalictrum maritimum seeds sampled in 2016 (A) and 2015 (B)

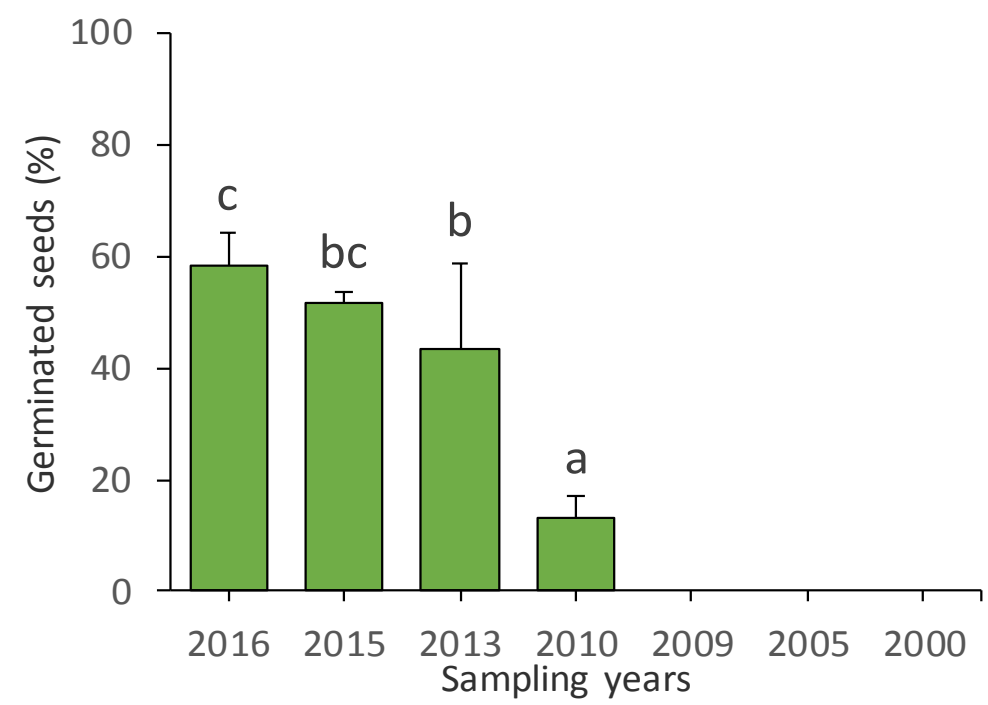

Fig. 2. Germination percentages, after 30 days of incubation, of Thalictrum maritimum seeds sampled in the indicated years and mechanically scarified before plating in the Petri dishes

Table 1. Effect of seed storage time on germination velocity, expressed as 'mean germination time' (MGT), in Thalictrum maritimum

\begin{tabular}{|c|c|c|c|c|c|c|}
\hline Sampling year & 2016 & 2015 & 2013 & 2010 & 2009 & 2005 \\
\hline MGT (days) & 12.6 & 10.5 & 14 & 17 & 0 & 0 \\
\hline
\end{tabular}

Next, T. maritimum seeds sampled in six different years, from 2000 to 2016, were germinated in plates after mechanical scarification - as this method appear to be the most efficient in stimulating germination (Fig. 2). This test confirmed the results of the previous experiment, with more than $50 \%$ of the seeds collected in 2016 and 2015 germinating after one month of incubation; this percentage decreased to about $40 \%$ for the 2013 seeds, and to less than $15 \%$ for seeds sampled in 2010; seeds from 2009 and previous years did not germinate at all (Fig. 2). Regarding germination velocity, it generally decreased with the age of the seeds, as reflected by the corresponding increase of MGT, although seeds from 2015 germinated faster than the most recent ones from 2016 (Table 1).

\section{Centaurea dracunculifolia}

Germination of $C$. dracunculifolia seeds did not require any specific pre-treatment since optimal results were obtained with seeds that had been simply disinfected but not treated in any other way. Fig. 3 and Table 2 show final germination percentages and germination velocity (MGT), respectively, in lots of seeds collected different years. Seeds sampled the last three years, 2014, 2015 and 2016, were those that germinated better, with average values up to ca. $80 \%$ in 2015. Lower germination percentages were calculated for seeds from previous years, down to less than $20 \%$ for 2012 and 2011; seeds sampled in 2010 or before did not germinate at all (Fig. 3). However, germination velocity did not seem to be so much affected by the storage 
time as the percentage of germination, and in some cases older seeds germinated faster (lower MGT) than younger ones (Table 2).

\section{Linum maritimum}

As for $C$. dracunculifolia, L. maritimum seeds showed high germination percentages without any specific pretreatment - except for cleaning and disinfection. All seeds stored for up to 10 years (samplings from 2007 to 2016) did not show statistically significant differences in germination percentages, with average values ranging from $\sim 70 \%$ to more than $80 \%$ (Fig. 4). Germination capacity decreased progressively in older seeds, down to less than $10 \%$ in those collected in 2002; no germination was observed for seeds sampled before that year (Fig. 4). Germination velocity was relatively high (low MGT) for seeds collected in 2011 or later, and then decreased in parallel with the increase in storage time, up to about five-fold higher MGT value for the 2002 seeds (Table 3).

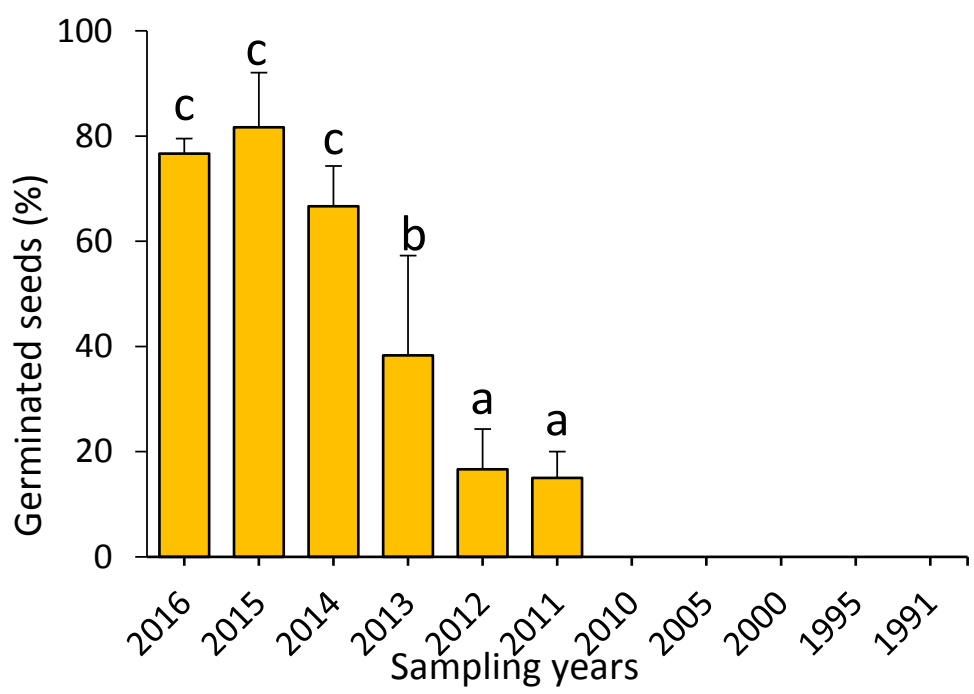

Fig. 3. Germination percentages, after 30 days of incubation, of Centaurea dracunculifolia seeds sampled in the indicated years

Table 2. Effect of seed storage time on germination velocity, expressed as 'mean germination time' (MGT), in Centaurea dracunculifolia

\begin{tabular}{|c|c|c|c|c|c|c|c|c|c|c|}
\hline Sampling year & 2016 & 2015 & 2014 & 2013 & 2011 & 2010 & 2005 & 2000 & 1995 & 1991 \\
\hline MGT (days) & 16.0 & 12.2 & 9.5 & 11.4 & 17.1 & 14.8 & 0 & 0 & 0 & 0 \\
\hline
\end{tabular}

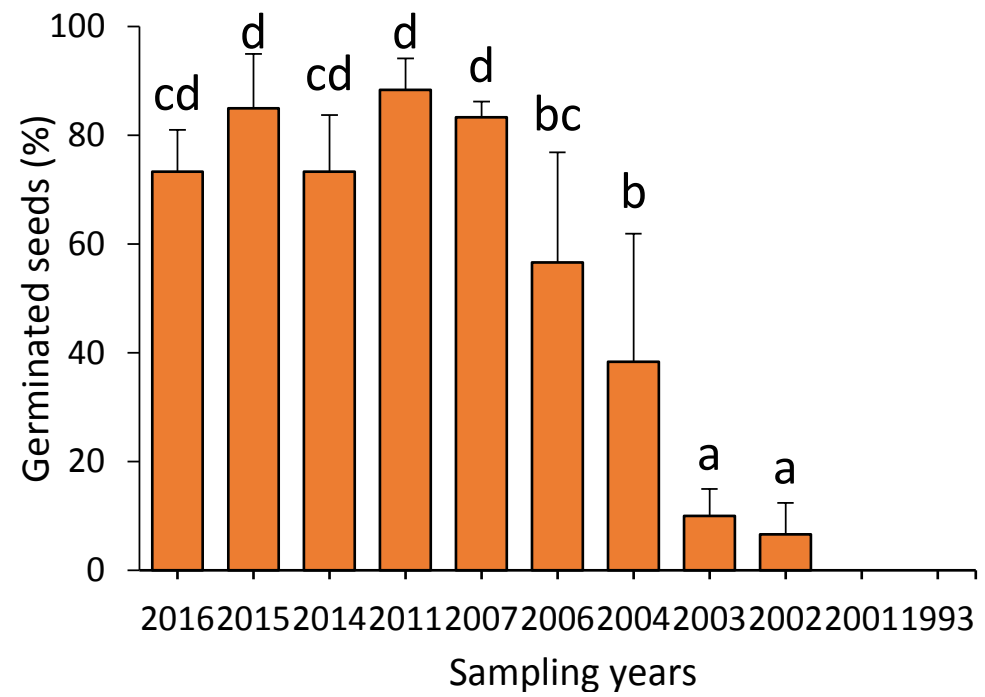

Fig. 4. Germination percentages, after 30 days of incubation, of Linum maritimum seeds sampled in the indicated years

Table 3. Effect of seed storage time on germination velocity, expressed as 'mean germination time' (MGT), in Linum maritimum

\begin{tabular}{|c|c|c|c|c|c|c|c|c|c|c|c|}
\hline Sampling year & 2016 & 2015 & 2014 & 2011 & 2007 & 2006 & 2004 & 2003 & 2002 & 2001 & 1993 \\
\hline MGT (days) & 4.3 & 3.6 & 3.6 & 4.5 & 6.4 & 9.1 & 11.9 & 16.5 & 21.5 & 0 & 0 \\
\hline
\end{tabular}




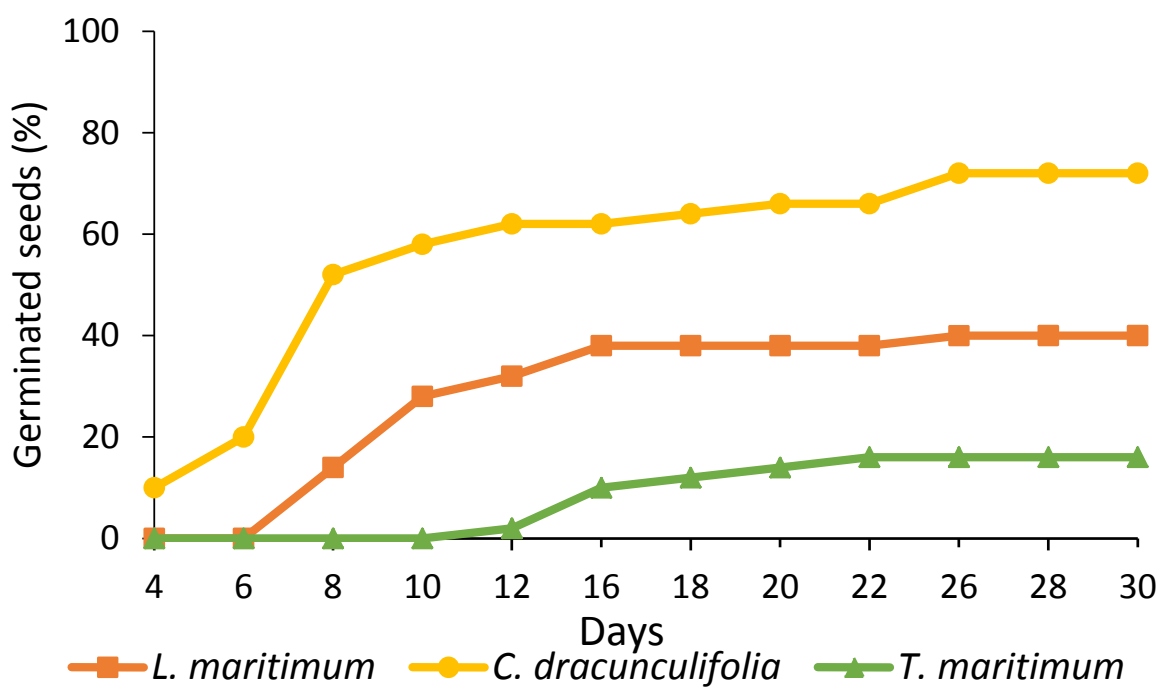

Fig. 5. Germination kinetics of seeds of the selected species, collected in 2016, during four weeks following sowing in a substrate of $50 \%$ peat, $25 \%$ perlite, and $25 \%$ vermiculite

Table 4.Viability of T. maritimum seeds tested by tetrazolium staining. Seeds completely stained are considered as 'viable'

\begin{tabular}{cccccccccc}
\hline Sampling year & 2016 & 2015 & 2014 & 2013 & 2010 & 2009 & 2005 & 1997 \\
\hline Completely stained (\%) & 85 & 75 & 55 & 60 & 0 & 0 & 0 & 0 \\
Partially stained (\%) & 15 & 25 & 35 & 30 & 0 & 0 & 0 & 0 \\
Not stained (\%) & 0 & 0 & 10 & 10 & 100 & 100 & 100 & 100 \\
\hline
\end{tabular}

Germination after direct sowing of seeds in substrate

Seeds of the three selected species sampled in 2016 that is, those stored for the shortest time - were sown directly in pots with a standard substrate to assess their germination capacity, as an alternative to germination in plates. The species that germinated best under these conditions was C. dracunculifolia, reaching about $70 \%$ germination four weeks after sowing, which is similar to the value obtained in the in vitro assay. For $L$. maritimum seeds, $40 \%$ germination was registered at the end of the assay, about half of that registered in the Petri dishes. T. maritimum was again the species that gave the worst results, barely reaching $15 \%$ of final germination percentage (Fig. 5).

\section{Viability tests}

Viability was checked only for T. maritimum seeds. After the tetrazolium test, the seeds were classified into different groups, as described in Methods. As shown in Table 4, the seeds of T. maritimum sampled prior to the year 2010 were no longer viable, in agreement with the result of the in vitro germination tests (Fig. 2). Seeds from the years 2013 to 2016 showed viability percentages generally increasing with the reduction of storage time, up to $85 \%$ for seeds collected in 2016 . These values are somewhat higher than the corresponding germination percentages (Fig. 2), indicating that not all viable seeds identified by the tetrazolium test are able to germinate under the conditions used in the in vitro assays.

\section{Discussion}

Seed collections that are to be used for conservation applications (e.g. in situ actions such as recovery or reintroduction programmes) must be representative of the species' genetic diversity, and ensure that the material will be available over the long term (Bacchetta et al., 2008; BGCI, 2012; Ferrer-Gallego et al., 2013; IUCN/SSC, 2014; Volis, 2015). Therefore, to assess the utility of ex situ collections for restoration programmes not only the number of accessions stored should be considered; knowledge of seed viability, germination capacity, and the overall capacity to produce new plants is also required, seed viability testing being perhaps the most important component (Godefroid et al., 2011).

The three species selected for this study have orthodox seeds that are optimal to be maintained in seed banks as they can withstand drying during storage. However, although they were stored under the same conditions, considerable differences were registered regarding their germination capacity after storage. Linum maritimum seeds were the most resistant, maintaining high (and not significantly different) germination percentages, over $70 \%$, after storage for up to 9-10 years, and lost completely their germination capacity only after more than 14 years. For $C$. dracunculifolia and. T. maritimum, however, germination capacity decreased significantly after more than three years of storage, although the maximum germination percentages were different in the two species: about $80 \%$ in the former and less than $60 \%$ in the latter. 
These results confirm the relatively rapid loss of seed viability during storage at room temperature, highlighting the need to assess the optimal conservation period for each particular species. This knowledge is necessary for the efficient management of these short-term, 'active' seed banks, allowing to plan the renewal of the seed collections at the most appropriate time, so that seeds with high germination capacity are always available to be used in conservation or restoration actions. The costs derived from the more frequent samplings and treatments of seeds to renew the collections are much lower than those of the infrastructure required for longer storage at low or ultralow temperatures (Pritchard and Dickie, 2003; Engelmann, 2004), as compared to keeping the seeds at room temperature. In the case of the seed bank of the ' $\mathrm{La}$ Albufera' Natural Park, affected by the typical Mediterranean climate with very hot summers, 'room temperature' can be too high during this season, and a standard air condition system is used to maintain the storage room at or below $18^{\circ} \mathrm{C}$.

It is also important to establish appropriate conditions for seed germination, which can also vary between different taxa. Seeds of $C$. dracunculifolia and L. maritimum showed optimal germination without any special pre-treatment, just a simple disinfection to avoid fungal contamination. Thalictrum maritimum seeds, on the contrary, did not germinate at all without a previous scarification treatment, and mechanical scarification with sandpaper appears to be the most effective.

From a practical point of view, regarding the species selected for this work, it should be recommended that seed collections of $C$. dracunculifolia and $T$. maritimum are replaced by newly collected samples every three years or at shorter times, whereas those of $L$. maritimum can be stored for up to 10 years. To generate new plants for conservation and reintroduction programmes, it is also recommended to germinate the seeds by sowing them directly on the substrate - although in vitro germination in Petri dishes gives generally higher germination percentages - as a simpler and more economical procedure which, in addition, reduces seedlings losses by transplantation. Seed germination in plates, however, is a convenient, simpler and less ambiguous alternative to the tetrazolium staining method to determine the viability of seeds before and during storage, as apparently viable, fully stained seeds may have lost their germination capacity.

In the particular case of $T$. maritimum, which is an endemic species with small populations and in risk of extinction, and other species in similar circumstances, the usual collection of seeds in the natural environment may be problematic; it could lead to the loss of the seed material needed to maintain population dynamics in nature. In these specific cases, the replication of populations with a high conservationist interest through ex situ plant collections should be considered. In this way, it will be possible to multiply the plants and generate seeds without affecting their natural populations.

The studies described here can be extended to seeds of other species of interest kept at the seed bank of the 'DevesaAlbufera' Service (and similar short-term germplasm banks) to help optimise its management and activities.

\section{Acknowledgements}

Lourdes Yabor was recipient of an EMBO Short-term fellowship, which financed her stay in Valencia.

\section{References}

Aguilella A, Fos S, Laguna E (Eds) (2010). Catálogo Valenciano de Especies de Flora Amenazadas [Valencian Catalog of Endangered Flora Species]. Colección Biodiversidad, 18. Conselleria de Medi Ambient, Aigua, Urbanismei Habitatge, Generalitat Valenciana, Valencia

Bacchetta G, Bueno Sánchez A, Fenu G, Jiménez-Alfaro B, Mattana E, Piotto B, Virevaire M (Eds) (2008). Conservación ex situ de plantas silvestres [Ex situ conservation of wild plants]. Obra Social La Caixa y Gobierno del Principado de Asturias, Asturias

Bañares Á, Blanca G, Güemes J, Moreno JC, Ortiz S (Eds) (2006). Atlas y Libro Rojo de la Flora Vascular Amenazada de España [Atlas and Red Book of the Endangered Vascular Flora of Spain]. Adenda 2006. Dirección General para la Biodiversidad-Sociedad Española de Biología dela Conservación de Plantas, Madrid.

Benson EE (2008). Cryopreservation of phytodiversity: a critical appraisal of theory \& practice. Critical Reviews in Plant Sciences 27:141-219.

BGCI - Botanic Gardens Conservation International (2012). Implementing ex situ conservation programmes. Botanic Gardens Conservations International, Richmond, UK

Bolòs O de, Vigo J (1984). Flora dels Països Catalans [Flora of the Catalan Countries].Vol 1. Barcino, Barcelona.

Bolòs Ode, VigoJ, Masalles RM, NinotJM (2005). Flora manual dels Països Catalans [Manual flora of the Catalan Countries]. $3^{\text {a }}$ Ed Pòrtic, Barcelona.

CBD (2002). Global Strategy for Plant Conservation. The Secretariat of the CBD and BGCI, Montreal, Canada and Richmond, UK.

CBD (2012). The Global Strategy for Plant Conservation: 2011-2020. Botanic Gardens Conservation International, Richmond, UK.

CITMA - Consellería de Infraestructuras, Territorio y Medio Ambiente (2013). Orden 6/2013, de 25 de marzo, de la Conselleria de Infraestructuras, Territorio y Medio Ambiente, por la que se modifican los listados valencianos de especies protegidas de flora y fauna. [Regulation 6/2013, passed 25 March 2013, of the Department of Infrastructures, Territory and Environment, to modify the Valencian lists of protected species of flora and fauna].DOCV.6996:8682-8690.

Craviotto RM, Arango MR (2005). Simiente de trigo: nueva herramientaen el control de calidad para mejorar la producción [Wheat seed: new tool in quality control to improve production]. INTA EEA Oliveros 31:4850.

Cuevas S, Jesús A (1988). Recursos Fitogenéticos. Bases conceptuales para el estudio y conservación [Phytogenetic Resources. Conceptual bases for the study and conservation]. Universidad Autónoma Chapingo Dpto. Fitotecnia, Chapingo, Mexico.

Curcó A (2007). Flora vascular del Delta de l'Ebre [Vascular flora of the Delta de l'Ebre]. Collecció Tècnica, 1. Generalitat de Catalunya, Departament de Medi Ambient i Habitatge, Parc Natural del Delta de l'Ebre. 1aEdició, Deltebre. 
570

Ellis R, Roberts EH (1981). The quantification of aging and survival in orthodox seeds. Seed Science and Technology 9:373-409.

Engelmann F (2004). Plant cryopreservation: progress and prospects. In Vitro Cellular and Developmental Biology Plant 40:427-433.

ENSCONET - European Native Seed Conservation Network (2009). ENSCONET seed collection manual for wild species. RBG Kew and Universidad Politécnica de Madrid, Kew and Madrid.

FAO (2013). Draft revised genebank standards for the conservation of orthodox seeds. Food and Agriculture Organization of the United Nations, Rome.

Ferrer-Gallego PP, Ferrando I, Gago C, LagunaE (Eds) (2013). Manual para la conservación de germoplasma y el cultivo de la flora valenciana amenazada [Handbook for germplasm conservation and cultivation of the Valencian threatened flora]. CITMA-Generalitat Valenciana, Valencia.

Ferrer-Gallego PP, Ferrando I, Albert FJ, Martínez V, Escriba MC, Navarro A, Laguna E (2014). Conservación y distribución de accesiones del Banco de Germoplasma de Flora Silvestre Valenciana en la colección CIEF [Accessions conservation and distribution in the CIEF collection of the Valencian Germplasm Bank of Wild Flora]. Cuadernos de Biodiversidad 46:9-18.

Ferrer-Gallego PP, Laguna E, Mateo G (2015). Neotipificación de Thalictrum maritimum Dufour (Ranunculaceee), planta endémica y amenazada del este peninsular ibérico [Neotyping of Thalictrum maritimum Dufour (Ranunculaceae), endemic and threatened plant of the Iberian peninsular east]. Flora Montiberica 59:83-87.

GodefroidS, Riviére S, Waldren S, Boretos N, Eastwood R, Vanderborght T (2011). To what extent are threatened European plantspecies conserved in seed banks? Biological Conservation 144:14941498.

Guerrant EO, Fiedler P, Havens K, Maunder M (2004). Revised genetic sampling guidelines for conservation collections of rare and endangered plants. In: Guerrant EO, Havens K, Maunder M (Eds). Ex situ plant conservation: supporting species survival in the wild. Island Press, Washington DC pp 419441.

Hernández-Bermejo JE (2007). Jardines botánicos y bancos de germoplasma: la conservación ex situ frente a la perspectiva de una estrategia para la conservación de las plantas [Botanic gardens and germplasm banks: ex situ conservation facing the challenge of a strategy for plant conservation]. Ambienta 65:40-47.

Heywood VH (2003). Mediterranean plant collections: needs and options. Setting the scene: what we have inherited. Bocconea 16(1):283-287.

Heywood VH (2015). In situ conservation of plant species: an unattainable goal? Israel Journal of Plant Science 63:211-231.
Hoban S, Schlarbaum S (2014). Optimal sampling of seeds from plant populations for ex-situ conservation of genetic biodiversity, considering realistic population structure. Conservation Biology 177:90-99.

Iriondo JM (2001). Conservación de germoplasma de especies raras y amenazadas (Revisión) [Conservation of germplasm of rare and threatened species]. Investigación agrarian. Producción y Protección Vegetal 16(1):5-24.

IUCN/SSC (2014). Guidelines in the use of ex situ management for species conservation. Version 2.0. IUCN Species Survival Commission, Gland, Switzerland.

Laguna $\mathrm{E}(\mathrm{Ed})$ (1998). Flora endémica, rara o amenazada de la Comunidad Valenciana [Endemic, rare or threatened flora of the Valencian Community]. Generalitat Valenciana, Consejería de Medio Ambiente, Valencia.

Lidón A, Boscaiu M, Collado F, Vicente O (2009). Soil requirements of three salt tolerant, endemic species from South-East Spain. Notulae Botanicae Horti Agrobotanici Cluj-Napoca 37(2):6470.

Mansanet J (1979). Flora y Vegetación de la Dehesa de La Albufera [Flora and Vegetation of the Dehesa de La Albufera]. Departamento de Botánica. Facultad de Ciencias. Universidad de Valencia, Valencia.

Mateo G, Crespo MB (2014). Claves Ilustradas para la Flora Valenciana [Illustrated guidelines for the Valencian flora]. Monografias de Flora Montiberica.Jolube Consultory Editor Botánico,Jaca.

Montserrat P (1986). Thalictrum L. In: Castrviejo S et al. (Eds) Flora Iberica 1:387-401. Real Jardín Botánico, CSIC, Madrid.

Pritchard HW, Dickie JB (2003). Predicting seed longevity: use and abuse of seed viability equations. In: Smith $\mathrm{RD}$, Dickie JB, Linington $\mathrm{SH}$, Pritchard HW, Probert RJ (Eds). Seed Conservation: Turning Science into Practice. Royal Botanic Gardens, Kew, UK, pp 653-722.

Sharrock S, Jones M (2011). Saving Europe's threatened flora: progress towards GSPC Target 8 in Europe. International Journal of Biodiversity and Conservation 20:325-333.

Sharrock S, Oldfield S, Wilson O (2014). Plant Conservation Report 2014: A review of progress and implementation of the Global Strategy for Plant Conservation 2011-2020. Secretariat of the Convention on Biological Diversity, Montreal, Canada and Botanic Gardens Conservation International, Technical Series 81, Richmond, UK.

Volis S, Blecher M (2010). Quasi in situ a bridge between ex situ and in situ conservation of plants. Biodiversity and Conservation 19:2441-2454.

Volis S (2016). Species-targeted plant conservation: time for conceptual integration. Israel Journal of Plant Science 63:232-249. 